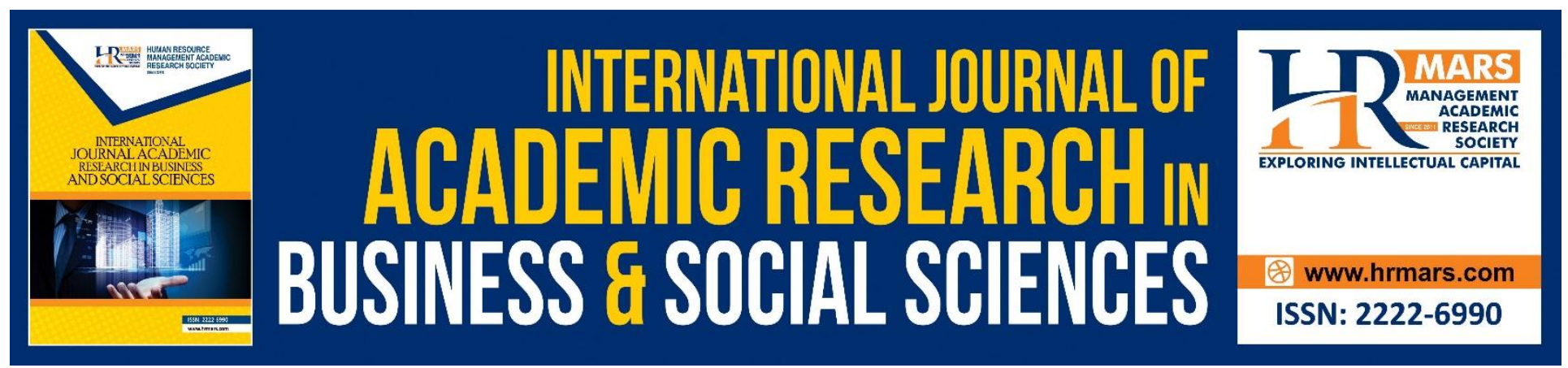

\title{
Developing an Interactive Multimedia Module for the Topic of Making Clothes: A Requirements Analysis
}

\section{Baity Bujeng, Arasinah Kamis, Suriani Mohamed, Farah Najwa Ahmad Puad}

To Link this Article: http://dx.doi.org/10.6007/IJARBSS/v8-i11/5342

DOI: $10.6007 /$ IJARBSS/v8-i11/5342

Received: 26 Oct 2018, Revised: 27 Nov 2018, Accepted: 03 Dec 2018

Published Online: 04 Dec 2018

In-Text Citation: (Bujeng, Kamis, Mohamed, \& Puad, 2018)

To Cite this Article: Bujeng, B., Kamis, A., Mohamed, S., \& Puad, F. N. A. (2018). Developing an Interactive Multimedia Module for the Topic of Making Clothes: A Requirements Analysis. International Journal of Academic Research in Business and Social Sciences, 8(11), 1688-1700.

Copyright: (C) 2018 The Author(s)

Published by Human Resource Management Academic Research Society (www.hrmars.com)

This article is published under the Creative Commons Attribution (CC BY 4.0) license. Anyone may reproduce, distribute, translate and create derivative works of this article (for both commercial and non-commercial purposes), subject to full attribution to the original publication and authors. The full terms of this license may be seen at: http://creativecommons.org/licences/by/4.0/legalcode

Vol. 8, No. 11, 2018, Pg. 1688 - 1700

Full Terms \& Conditions of access and use can be found at http://hrmars.com/index.php/pages/detail/publication-ethics 


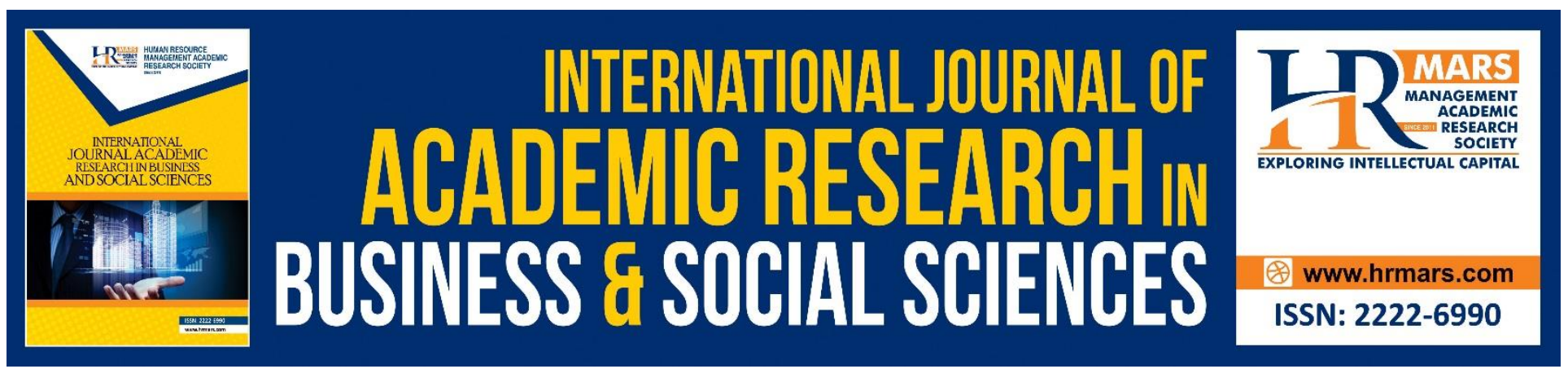

\section{Developing an Interactive Multimedia Module for the Topic of Making Clothes: A Requirements Analysis}

\section{Baity Bujeng, Arasinah Kamis, Suriani Mohamed, Farah Najwa Ahmad Puad}

Faculty of Technical and Vocational Education, Universiti Pendidikan Sultan Idris, 35900 Tanjong Malim, Perak, Malaysia

\section{Abstract}

This study discusses the analysis results of the requirements carried out as a first step in constructing an interactive multimedia module for learning and facilitating (LFc) the topic of making clothes. Respondents consist of 13 Home Science teachers and 166 form five students from different secondary schools in the northern zone of Sarawak. The purpose of this analysis is to identify the normative requirements of the topics contained in Home Science Standards of Content and ascertain the perception and student-sense needs. This requirement analysis of students is also done from the perspective of teachers as individuals who are directly involved in the learning and facilitation of Home Science. The results show that the topic of making clothes is considered as a very difficult subject by the teachers and students. The results of the comprehension test on the topic of making clothes also show the students' low level of achievement. Although the teachers use multimedia software to teach the topic of making clothes, it is found that the software used to teach the topic is incomplete and does not conform to the Home Science Standards of Content.

Keywords: Interactive Multimedia Module, Making Clothes, ICT, ASSURE Model, Home Science, normative requirement, the feel of need.

\section{Introduction}

The goal of Technical Vocational Education and Training (TVET) is to produce individuals who are knowledgeable, technically skilled, innovative, equipped with problem-solving skills, and have the ability to produce goods and services (Mohamed Nor and Ramlee, 2015). The government has been intentionally injecting TVET into the academic curriculum of the school system through the introduction of a number of related subjects at the primary, lower secondary and upper secondary levels. These new elements of learning are explicitly stated in the curriculum as higher order thinking skills (HOTS), entrepreneurship, ICT skills, a practice of positive attitude and values (KPM, 2016).

The 21st century learning introduced in the Malaysian education system has emphasized the literacy elements of information and communication technology (MOE, 2014). It covers how teachers use information and communication technology (ICT) to carry out teaching and learning (T\&L) with 
more quality and effectiveness (Sarkar, 2012). Teachers play the role of a mentor in individual or group learning activities when they use teaching media (Maimon et al., 2011, Norasiah, Nor Risah \& Rosnah, 2013). Therefore, teachers should be creative and innovative in using the teaching technology so that learning will be more effective, interesting and fun. According to Michael Fullan, it is time for technology to be instrumental in the transfer of knowledge from teachers to students in the 21st century (Schrum \& Lewin, 2015). The Ministry of Education Malaysia (MOE) believes that ICT is able to help strengthen the $T \& L$ process as students can access the learning content easily, interestingly and interactively (Syed Ismail \& Ahmad Subki, 2010; Sarkar, 2012). Through the ICT network systems, teaching materials can be produced more efficiently while educators can provide a more effective teaching approach, and various T\&L techniques can be applied in the classroom (Donkor, 2011; Sarkar, 2012; El-Sayed \& El-Sayed, 2012; Norasiah et al., 2013; MOE, 2013).

Acquisition of knowledge and skills of TVET students has yet to reach the established standard compared with ordinary high school students (Korkmaz, 2011). Previous studies have shown that students' mastery of the theory and practical skills of clothing and sewing components is still at a moderate level (Dalilah, Suriani \& Nur Ainil, 2014; Tee at al., 2016). Students' achievement can be improved if the students are often exposed to attractive and interesting $T \& L$ methods (Tee at al., 2016). Student willingness and motivation should also be improved (Dalilah et al., 2014) because the lack of practical mastery is due to the perfunctory attitude, lack of interest and lack of guidance from instructors (Tee at al., 2016). The lack of interest and guidance will affect the students' learning outcomes (Azubuike, 2011; Abdull Sukor, Nurahimah, Izam, Rafisah \& Nur Fatirah, 2014). In reality, teachers still do not have effective techniques in creating a learning environment that can attract students' interest and attention (Yusmarwati, Rohayu \& Halizah, 2015; Uwameiya, 2015).

Teaching and learning based on ICT and multimedia methods are often said to have a positive impact on these aspects: memory conservation (Oberfoell \& Correia, 2016; Yap, 2016; Yuksel \& Yuksel, 2015), understanding, skills acquisition (Eital, 2016; Linder, Eital, Strobel \& Kohler, 2016; Yuksel \& Yuksel, 2015; Zurina \& Maizam, 2015; Leow \& Neo, 2014), and student motivation (Yanika et al., 2017; Leow \& Neo, 2014). However, ICT is not fully utilized by teachers (MOE, 2013; Jinnah, AlMamun, Khan \& Hassan, 2011). Integration of ICT in the teaching process remains at a low level (Irfan Naufal \& Amat Sazali, 2015) because teachers are not very knowledgeable in applying ICT in their T\&L (Khan \& Markauskaite, 2017; Jinnah et al., 2011). As such, teachers need to be provided with multimedia-based materials in their T\&L so that the aims of learning can be achieved (Beers, 2011). Some teachers use multimedia software to teach the topic of making clothes, but the software they use is incomplete, not interactive and less systematic. Teachers encounter difficulties in applying the interactive multimedia learning modules developed by multimedia specialists because they do not quite understand the syllabus, and the imported multimedia modules are not in line with the education context of Malaysia (Siti Zulaidah, Mohamed \& Mai Shihah, 2017).

Based on the identified problems, the researcher will develop an interactive multimedia teaching module for the topic of making clothes (MIMP). The software package will employ ICT-based media and technology so that Home Science teachers can use it in learning and facilitating (LFC) the topic of making clothes. This study was conducted as a starting point to construct an interactive multimedia module in LFc for the topic of Making Clothes. The aim of the research is to identify the normative requirements in terms of perceptions and requirement of students and teachers on the topics based 
INTERNATIONAL JOURNAL OF ACADEMIC RESEARCH IN BUSINESS AND SOCIAL SCIENCES

Vol. 8, No. 11, Nov, 2018, E-ISSN: 2222-6990 @ 2018 HRMARS

on the Home Science Standards of Content. The purpose of this requirement study is to determine whether the researcher can proceed with the module construction process (Sidek \& Jamaludin, 2005).

\section{LITERATURE REVIEW}

\section{Multimedia Module}

The module is a teaching package (Rusell, 1974) and contains small sections that are complete and closely related to each other (Sharifah, 1981). In addition, the module is also a unit of teaching and learning that deals with a particular topic systematically and sequentially; it helps students to learn and master a learning unit (Sidek \& Jamaludin, 2005) easily, quickly and precisely, regardless of any assistance from the facilitator (Jamaludin, 2016). The would-be built-in module should consider the various rules and procedures so that the module produced really has the best effect on learning (Sidek \& Jamaluddin, 2005). This means the success or failure in achieving the objectives of a module depends on the procedures followed by the module builder. The use of such a module in T\&L has proven to increase the mastery and achievement of students in learning (Muhammad et al., 2016; Wingo et al., 2015; Noor Miza, 2015; Zuraini, 2014) and to attract the attention of and motivate students (Wingo et al., 2015; Noor Miza, 2015; Zuraini, 2014).

A multimedia package is a combination of text, video, graphics, interactive animation and audio (Smaldino, Lowther \& Russell, 2012). Based on some studies Mayer (2014), a combination of text and pictures is better than just explaining the text. An individual's memory will last longer if a combination of pictures and audio is displayed. A combination of media simplifies complicated and abstract concepts delivered. Every medium used in presentation can help to reinforce the understanding of students efficiently (Linder, Eital, Strobel \& Koller, 2016; Eital, 2015; Abu-Obaidah, Bakar, Hamzah \& Asmiran, 2012; Lachs, 2010). In addition, through multimedia, users can communicate, interact and create something that facilitates learning (Khan, Bibi \& Hasan, 2016; Norasiah et al., 2013; Lachs, 2010). The concept of interactivity is a criterion that must exist in the building of any multimedia software (Mohd Nor et al., 2012) which is able to motivate students in learning new things (Yanika, et al., 2017).

\section{ASSURE Model}

The ASSURE model is designed for teaching and learning that contains six steps to produce learning materials. Based on Merrill, Drake, Lacy dan Pratt (1996), teaching design can also be considered as a framework for developing modules. The ASSURE model has been selected to develop the interactive multimedia module as the former focuses on students and helps achieve learning objectives. Additionally, this model has easy steps to follow (Dela Rosa \& Vital, 2016), which are especially useful for new or inexperienced teachers to apply the T\&L processes in delivering quality teaching to students (Nurul Iman, 2017). Teachers can use the ASSURE model as a guide to design a teaching method that integrates technology and media (Dela Rosa \& Vital, 2016; Sezer, Yilmaz \& Yilmaz, 2013; Smaldino et al., 2012). Figure 1 shows the steps of the module in the construction process based on the ASSURE model (Heinich, Molenda \& Russel, 1993). ASSURE is an acronym formed based on the first letters of the steps in this model (Sezer et al., 2013). 


\section{Requirements Analysis}

According to Morisson, Ross \& Kemp (2007), identifying the problems of instruction is the beginning of the module construction procedure. Problems of instruction can be identified through requirements assessment, goal analyses and assessments of performance. The process focuses on the outcome, setting priorities, and determining what to do (Barbazette, 2006; Witkin \& Altschuld, 1995). The requirements study is an important step to determine whether the module construction process can be continued or otherwise (Sidek \& Jamaludin, 2005). In this study, the researcher carried out a requirements assessment on HS teachers and form-five students who took HS as an elective subject in the secondary school. There are three phases in the requirements analysis: exploring, gathering and analyzing data, and making decisions (Witkin \& Altschuld, 1995). The description of each phase of the requirements analysis for this study is shown in Table 2 below.

Table 2: Phase analysis of the construction requirement of Interactive Multimedia Making Clothes (MIMP) module.

\begin{tabular}{|l|l|l|}
\hline Explore "what is" & Gather \& Analyze data & Make decision \\
\hline Identify the requirements of the & Collect information from & $\begin{array}{l}\text { Determine the priority of } \\
\text { target group to determine the }\end{array}$ \\
Phase I to determine which & $\begin{array}{l}\text { problems to be } \\
\text { focus and scope of the } \\
\text { target groups and problems } \\
\text { requirements; obtain a } \\
\text { are most important; analyze } \\
\text { commitment for each analysis } \\
\text { step, including planning and } \\
\text { the causes and summarize } \\
\text { implementing the program. }\end{array}$ & $\begin{array}{l}\text { establish the treatment that } \\
\text { will be used to solve the } \\
\text { problems. }\end{array}$ \\
\hline
\end{tabular}

\section{OBJECTIVES OF THE STUDY}

An analysis of the requirements is carried out to identify these objectives:

1. The degree of difficulty of the topic of making clothes from the perspectives of Home Science (HS) teachers and students

2. The normative requirements of students in the topic of making clothes; and

3. The requirements of students in the subject of making clothes.

\section{METHODOLOGY}

\section{Research Design}

This study is a survey which aims to identify the students' performance gap in the topic of making clothes; the results will help the researchers decide whether the gaps need to be improved through treatment. This requirements analysis study is conducted in the schools of the North Zone of Sarawak. HS teachers and form-five students who take the HS subject at the secondary level of the five secondary schools are involved in the data collection process of this study. The time allocated for the teachers to answer the questionnaire on the difficulty level of the topic is 5 minutes; they only need 
INTERNATIONAL JOURNAL OF ACADEMIC RESEARCH IN BUSINESS AND SOCIAL SCIENCES

Vol. 8, No. 11, Nov, 2018, E-ISSN: 2222-6990 @ 2018 HRMARS

to indicate the level of difficulty for the form-four topics of HS based on the standard of content using the given scale. For form-five students, they need to answer the comprehension test in 60 minutes, and to answer a questionnaire (difficulty level of the topic and T\&L in Making Clothes) in 15 minutes.

\section{Research Sampling}

The sample consist of 13 HS teachers and 166 form five students from five national secondary schools in North Zone of Sarawak. Respondents involved 13 female teachers, 26 male students and 140 female students. Table 2 shows the background of teachers and students according to ethnicity.

\begin{tabular}{|c|c|c|c|c|c|}
\hline \multicolumn{6}{|c|}{$\begin{array}{l}\text { Table } 2 \\
\text { Background of teachers and pupils by ethnicity }\end{array}$} \\
\hline \multirow[t]{2}{*}{ Respondent } & \multicolumn{5}{|c|}{ Ethnic } \\
\hline & Malay & Chinese & $\begin{array}{l}\text { Native Community of Sabah / } \\
\text { Sarawak }\end{array}$ & Others & Total \\
\hline Teacher & 6 & 2 & 5 & 0 & 13 \\
\hline Student & 55 & 11 & 98 & 2 & 166 \\
\hline
\end{tabular}

\section{Research Instruments}

There are three instruments involved in this requirements analysis: the questionnaire for gauging the difficulty level of the topic of making clothes; the comprehension test of making clothes; and the T\&L feedback questionnaire. The Questionnaires for finding out the difficulty level of the subjects were given to HS teachers and form-five students. The aim of the questionnaire given to the teachers is to assess the degree of difficulty of the topics in the form-four HS standard of content. The T\&L feedback questionnaire and the comprehension test were only given to form-five students. This is done according to the rationale that the form-five students have covered all the standard content of HS while they were in form four. Comprehension test of the topic of making clothes is aimed to identify the normative requirements by comparing the students' achievements with the scoring schemes provided by the researchers. Only students of one school are chosen to sit for this test for a limited time.

The T\&L's feedback questionnaire consists of four constructs, namely emotional construct on the topic of making clothes, understanding the concept of making clothes, confidence, and T\&L's tools. This questionnaire is used to identify the requirements of the students in learning the topic of making clothes. The instruments in this study have been adapted from Lee's (2013) study while the comprehension test of making clothes was constructed by the researchers. A Pilot study was conducted to obtain the reliability of the instruments. The results of the pilot study show an alpha value of .91 for subject difficulty level questionnaire and an alpha value of .71 for T\&L feedback questionnaire. The content validation was carried out; the lecturers and teachers who were appointed as National Trainers for HS subjects reviewed all the instruments developed for this study.

\section{Data Analysis}

Data collected from all the instruments are processed and arranged in the form of tables to create an analytical report. The difficulty levels of the topics are analyzed using mode, mean and 
standard deviation to compare the data of the teachers and students. The data from T\&L feedback questionnaire are also analyzed in the form of means to make comparisons between the constructs. The students' answers in the comprehension test of making clothes are reviewed in accordance with the scoring scheme provided by the researcher. Each correct answer is given 1 mark, and no mark is given for the wrong answer or without answer. The full score for the test is 40 and the number of scores obtained by the respondents are converted to percentage. The percentage of the test obtained by the student depicts the level of mastery of the concept of making clothes. The level of mastery is divided into three stages: $0-40 \%$ indicates a low level of mastery; $41-79 \%$ indicates a moderate level of mastery; and $80-100 \%$ indicates a high level of mastery.

\section{RESEARCH FINDINGS}

After all the data are collected, they are analyzed and the analysis results are the main priorities of the module construction requirements. For the data related to the difficulty level of making clothes, the researchers sort the data according to the main requirements based on teachers and students categories. The topic that gains the highest mean is considered as the most difficult, while the topic with the lowest mean is considered as the simplest. The mean scores of the teachers and students are compared to identify the most important requirement from the perspectives of the teachers and students. Table 3 shows the formulation and comparison of data between the perceptions of the teachers and students.

\begin{tabular}{|c|c|c|c|c|c|c|c|}
\hline \multirow[t]{3}{*}{ Num } & \multirow[t]{3}{*}{ Topic } & \multicolumn{6}{|c|}{ Difficulty level } \\
\hline & & \multicolumn{3}{|l|}{ Teacher } & \multicolumn{3}{|l|}{ Student } \\
\hline & & Mean & $\begin{array}{l}\text { Standard } \\
\text { Deviation }\end{array}$ & Mode & Mean & $\begin{array}{l}\text { Standard } \\
\text { Deviation }\end{array}$ & Mode \\
\hline 1 & Food and nutrition & 2.31 & .855 & 2 & 2.20 & .780 & 2 \\
\hline 2 & Diet & 2.46 & .776 & 2 & 2.54 & .843 & 2 \\
\hline 3 & Digestion and absorption & 3.77 & .927 & 4 & 3.45 & .891 & 4 \\
\hline 4 & Food selection & 2.31 & .630 & 2 & 2.38 & .835 & 2 \\
\hline 5 & Cooking principles & 2.31 & .751 & 2 & 2.36 & .874 & 2 \\
\hline 6 & Dish management & 2.38 & .650 & 2 & 2.45 & .863 & 3 \\
\hline 7 & Food Sanitation & 2.31 & .947 & 3 & 2.47 & .865 & 3 \\
\hline 8 & Research in Fabrics & 3.62 & .768 & 3 & 3.30 & .937 & 3 \\
\hline 9 & Sewing Equipment & 1.85 & .800 & 1 & 2.75 & .981 & 3 \\
\hline 10 & Clothing selection & 2.62 & .869 & 2 & 2.93 & .942 & 3 \\
\hline 11 & Making Clothes & 4.31 & .751 & 5 & 4.02 & .687 & 4 \\
\hline 12 & Wardrobe & 2.38 & 1.193 & 2 & 2.96 & .978 & 3 \\
\hline 13 & Family Management & 2.15 & .899 & 3 & 2.21 & .879 & 2 \\
\hline 14 & Residence and Technology & 2.1538 & 1.06819 & 1 & 2.2711 & .841 & 2 \\
\hline
\end{tabular}

Based on Table 3, the findings show that the topic of Making Clothes is the most difficult in the Form-Four HS Standards of Content. Teachers and students who were the respondents of this study had the same perceptions about the difficulty level of the topic; the mean score for the teachers is 4.31 and that for the students is 4.02 . The second most difficult subject according to the perceptions 
of teachers and students is Digestion and Absorption, with a mean score of 3.77 for teachers and 3.45 for students. While the third most difficult topic is Research in Fabrics, with a mean score of 3.61 for teachers and 3.30 for students. Table 3 also shows that the majority of teachers consider the topic of Making Clothes as a very difficult subject with a mode value of 5 , and the majority of students consider it as a difficult topic with a mode value of 4 . The topic of Digestion and Absorption is grouped together with difficult topics, with a mode value of 4 for both groups of respondents.

The comprehension test of making clothes was assessed with the use of the scoring scheme provided by the researcher. Each student's score was calculated to determine his or her level of proficiency based on a set score range. Table 4 shows the formulation of the test scores on the comprehension test of making clothes and the mastery level in the topic of Making Clothes. Based on Table 5, it is significant to note that the level of students' mastery in the topic of Making Clothes is low. The scores of 45 students range from 0 to 40 percent while the other 4 students' scores range from 41 to 79 percent.

\section{Table 4}

The formulation of comprehension test in making clothes and the degree of mastery of the students.

\begin{tabular}{|l|l|l|l|}
\hline Num & Score range & Mastery level & Total of Students \\
\hline 1 & $80-100$ & High & 0 \\
\hline 2 & $41-79$ & Average & 4 \\
\hline 3 & $0-40$ & Low & 45 \\
\hline & & Total & 49 \\
\hline
\end{tabular}

The data from the feedback questionnaire on teaching and learning were analyzed in order to identify the requirements of students based on the four constructs, namely the emotional need on the topic of making clothes, the understanding of the concept of making clothes, the confidence to answer the questions of making clothes, and the necessary teaching materials needed in LFc of making clothes. Table 5 shows the data formulation based on the four pre-defined constructs.

\section{Table 5}

Summary of data on T\&L feedback questionnaire of Making Clothes

\begin{tabular}{|l|l|l|l|l|l|l|l|}
\hline Num & Construct & \multicolumn{3}{|l|}{ Item Mean } & \multicolumn{3}{|l|}{ Total Mean } \\
\hline 1 & $\begin{array}{l}\text { Emotion on the topic of making } \\
\text { clothes }\end{array}$ & 3.42 & 2.77 & 3.09 & 3.31 & 3.60 & 3.24 \\
\hline 2 & $\begin{array}{l}\text { Understanding the concept of } \\
\text { making clothes }\end{array}$ & 2.78 & 2.96 & 2.78 & 2.77 & 2.98 & 2.85 \\
\hline 3 & $\begin{array}{l}\text { Confidence in answering the } \\
\text { questions of making clothes }\end{array}$ & 2.88 & 4.14 & 3.09 & 3.68 & - & 3.45 \\
\hline 4 & Teaching tools in making clothes & 3.11 & 3.25 & 4.04 & 2.49 & 3.67 & 3.31 \\
\hline
\end{tabular}

Based on Table 5, the mean range for the construct of emotion on the topic of making clothes is from 2.77 to 3.09; the mean range for the construct of students' understanding on the concept of 
making clothes is from 2.77 to 2.98; the mean range for the construct of students' confidence in answering the question of making clothes is between 2.88 and 4.14 ; and the mean range for the construct of teaching tools in making clothes is between 2.49 and 4.04 . The total mean score for the construct of emotion on the topic of making clothes is 3.24, the understanding of the concept of making clothes is 2.85 , the construct of students' confidence in answering the question of making clothes is 3.45 , and the construct of teaching tools in making clothes is 3.31 .

\section{Discussion}

The Degree of Difficulty of the Topic of Making Clothes from the Perspectives of Home Science (HS) Teachers and Students

Based on the results of data analysis, the researcher found that teachers and students have the same perception of the level of difficulty in the topic of making clothes. Referring to Table 3 , the teachers and students consider the topic of Making Clothes as the most difficult in the Form-Four HS Standards of Content. The topic of Digestion and Absorption is the second most difficult, followed by the topic of Research in Fabrics. The majority of the teachers consider the topic of Making Clothes as the most difficult subject with a frequency of 5, while the majority of the students are of the opinion that the topic of Making Clothes is a difficult topic with a frequency of 4 . Making Clothes is one of the knowledge-based skills (theory) (Tee et al., 2016). In the theoretical learning, the level of understanding includes the explanation of concepts and discussions in the classroom. The practical part consists of the technical skills of students based on the application of the theories studied in practical classes or everyday life (Tee at al., 2016). This means that students need to master and understand the theory of the sewing processes before they can apply the knowledge in making clothes.

\section{The Normative Requirements of Students in the Topic of Making Clothes.}

Based on the summary data of the comprehension test on the topic of Making Clothes in Table 5,45 out of 49 students obtained scores ranging from 0 to 40 percent. This shows that majority of the students have a low level of mastery in the topic of Making Clothes. Most students left empty space in the test paper given to them, and did not try to answer the given questions. The answers given by the students also show that they are weak in the knowledge of the topic of Making Clothes. Some respondents wrote these comments on their test papers: 'forget' (R45, R42, R40, R39, R38, R37, R36, R35, R26, R24, R12, R9, R8, R7, R6, R5), 'difficult questions' (R45, R40, R39, R37, R36 ,R35, $R 31, R 27, R 24, R 8, R 7, R 6)$, and 'not doing revision' (R27, R12). These comments are a form of feedback that shows that most of the students did not perform well in the test due to the unacceptable excuses such as forgetfulness, the assumption of difficult questions, and not doing revision.

\section{The Requirements of Students in the Subject of Making Clothes.}

A summary of data obtained from the T\&L feedback questionnaire is shown in Table 6. The questionnaire is divided into four constructs, namely the students' emotion on the topic of making clothes, understanding of the concept of making clothes, the confidence in answering the questions of making clothes, and the necessary tools in T\&L of making clothes. Based on the findings, it can be 
concluded that although the students' understanding of the concept of making clothes is low (mean of 2.85), their confidence in answering the questions is quite good with a mean score of 3.45 . The researcher found out that the students had trouble understanding the sewing process (mean of 2.78), could not imagine the process of preparing the sewing process (mean of 2.96), and compared the sewing process for each of stitching process (mean of 2.98). However, students feel confident that they will better understand the process of making clothes if they work harder (mean of 4.14), and feel confident that their achievement in the final year examination will be better (mean of 3.68). Although the teacher uses multimedia in teaching the subject of making clothes (mean of 3.11), students need further help in the form of animated illustration, video and simulation, and diagrams in multimedia software to better understand the sewing processes of making clothes (mean of 4.04). Students also mentioned that they love to learn the subject of making clothes using multimedia software (mean of 3.66) and do not like to have sewing classes after the school hours (mean of 2.49).

The space for comments and posts in the T\&L feedback questionnaire gives the students an opportunity to write comments or suggestions on the topic of making clothes. Based on the comments given by the students, the researcher concludes that the students like to learn the HS subjects, enjoy and are interested in learning the topic of Making Clothes. However, sometimes, the topic of making clothes is dull and causes some of the students to lose interest, and they think that the topic is difficult to understand. The sewing process is long and tedious; it is hard for students to remember all the sewing steps. Due to the lengthy sewing process and the difficulty to understand the details, the students are not able to produce presentable or marketable outfits. Therefore, the students hope that teachers will be able to provide clearer and more detailed T\&L methods that are more interesting and easy to understand. According to a study Azubuike (2011), the lack of interest and guidance from instructors will affect student learning. Additionally, students also hope that teachers can use interesting technology and multimedia in their teaching.

\section{CONCLUSION}

The results from the requirements analysis provide a clearer picture of the requirements and problems faced in the LFc of making clothes topic in the Sarawak secondary schools. Overall, teachers and students consider Making Clothes as the most difficult topic in the standard of content of HS subject in form four. The comprehension test on the topic of making clothes has shown that the students' level of mastery is low, and this indicates that the normative requirements of the students are high. Students' requirements are at a moderate level. The majority of the students need help in terms of animation, video, simulations and diagrams to understand the sewing processes that are considered to be difficult. Hence, the researchers will incorporate animation elements, videos, simulations and related diagrams in constructing the MIMP module. Although the students' understanding of the concept in making clothes is low, their level of confidence is quite good. By applying the Behaviorism learning theory in constructing the MIMP module, the researcher attempts to increase the students' interest and motivation in learning the topic of Making Clothes. The application of scaffolding techniques in the MIMP module is also expected to help students in mastering the topics that are considered to be difficult.

Hence, the researchers suggest that further research should be conducted by involving more respondents to obtain a more comprehensive picture of the issue. 
INTERNATIONAL JOURNAL OF ACADEMIC RESEARCH IN BUSINESS AND SOCIAL SCIENCES

Vol. 8, No. 11, Nov, 2018, E-ISSN: 2222-6990 @ 2018 HRMARS

\section{References}

Shaari, A. S., Yusoff, N. M., Ghazali, I. M., Osman, R. \& Dzahir, N. F. M. (2014). The relationship between lecturers' Teaching style and students' academic engagement. Procedia Social and Behavioral Sciences, 118: 10-20.

Bakar, A. R, Hamzah, R. \& Asmiran, S. (2012). Teachers' ICT Skills and ICT Integration in the Classroom: The case of Vocational and Technical Teachers in Malaysia. Creative Education, 3(8), 70-76.

Azubuike, O.C. (2011). Influential factors affecting the attitude of students toward vocational/technical subjects in secondary schools in Southeastern Nigeria. Journal of Education and Social Research, 1(2): 49-56.

Barbazette, J. (2006). Training Needs Assessment: Methods, Tools and Techniques. USA: John Wiley \& Son. Retreived from https://books.google.com.my/books?isbn=0787975257

Beers, S. Z. (2011). 21 $1^{\text {st }}$ Century Skills: Preparing Students for their future. Mc Graw Hill Education. Retrieved from https://cosee.umaine.edu/files/coseeos/21st_century_skills.pdf.

Dela Rosa, J. P. O \& Vital, R. A. D. (2016). The Use of Facebook in Argumentative Writing: Towards an Instructional Design Model. AsTEN Journal of Teacher Education, 1(2), 39-58.

Donkor, F. (2011). Assessment of learner acceptance and satisfaction with video-based instructional materials for teaching practical skill at a distance. The International Review of Research in Open and Distributed Learning, 12(5), 74-92.

El-Sayed, R. E. H., \& El-Sayed, S. E. A. E. (2012). Video-based lectures: An emerging paradigm for teaching human anatomy and physiology to student nurses. Alexandria Journal of medicine, 49, 215-222.

Eital, A. (2015). How repeated studying and testing affects multimedia learning: Evidence for adaptation to task demands. Learning and Instruction, 41, 70-80.

Umar, I. N. \& Hassan, A. S. A. (2015). Malaysian teachers' level of ICT integration andlts perceived impact on teaching and learning. Procedia-Social and Behavioral Sciences, 197: 2015-2021.

Jamaludin, A. (2016). Modul Motivasi Diri. Cetakan Ketiga. In Malay. Kuala Lumpur: Dewan Bahasa dan Pustaka.

Jinnah, M. A., Al-Mamun, M. A., Khan, M. S. H. \& Hasan, M. (2011). ICT in vocational teaching/learning and research in Southeast Asian Countries: A case of Bangladesh. International Journal of Vocational and Technical Education, 3(2), 20-28.

Khan, M. S. H., Bibi, S., \& Hasan, M. (2016). Australian Technical Teachers' Experience of Technology Integration in Teaching. Retrieved 9 October 2016, from https://us.sagepub.com/enus/nam/open-acces-at-sage

Khan, M.H. \& Markauskaite, L. (2017). Approaches to ICT-enhance teaching in technical and vocational education: a phenomenographic perpective. Higher Education, 73:691. https://doi.org/10.1007/s10734-016-9990-2

Korkmaz, O. (2011). Academic achievement and opinion of CEIT students graduating from vocational high school. Procedia-Social and Behavioral Sciences, 28, 23-28.

Lachs, V. (2010). Making Multimedia in the classroom. United Kingdom: Taylor \& Francis Books Ltd.

Lee, T.T. (2013). Pembinaan dan Keberkesanan Modul Multimedia Interaktif dengan Agen Pedagogy dalam pembelajaran Elektrokimia (Doctoral dissertation). In Malay. Universiti Kebangsaan Malaysia, Bangi. 
INTERNATIONAL JOURNAL OF ACADEMIC RESEARCH IN BUSINESS AND SOCIAL SCIENCES

Vol. 8, No. 11, Nov, 2018, E-ISSN: 2222-6990 @ 2018 HRMARS

Leow, F. T., \& Neo, M. (2014). Interactive multimedia learning: Innovating classroom education in a Malaysian university. Turkish Online Journal of Educational Technology, 13(2), 99-110.

Linder, M. A., Eital, A., Strobel, B \& Koller, O. (2016). Indentifying processes underlying the multimedia effect in testing: An eye-movement analysis. Learning and Instruction, 47(2017), 91-102.

Mayer, J. (2014). The Cambridge handbook of multimedia learning $2^{\text {nd }}$ ed. Cambridge: Cambridge University Press.

Merrill, M.D., Drake, L., Lacy, M.J., Pratt, J. (1996). Reclaiming instructional design. Educational Technology, 36(5), 5-7.

Morrison, G. R.,Ross, S. M., \& Kemp, J. E. (2007). Designing Effective Instruction (5 ${ }^{\text {th }}$ Edition). NJ: John Wiley \& Sons, Inc.

Muhammad Asri Madmor, Tee, T. K., Mohamed Nor Azhari Azman, Ridwan Che Rus, Zaliza Hanafi, Jailani Md Yunos et al. (2016). Modul Peta Buzan dan Pencapaian pelajar Pendidikan Asas Vokasional di Malaysia: Satu Kajian Keberkesanan. In Malay. Georgrafia Online, Malaysia Journal of Society and Space 12(3), 139-144. ISSN 2180-2491

Noor Miza, A. R. (2015). Pembinaan Modul Berasaskan Pendekatan Projek Untuk meningkatkan Kemahiran Berkomunikasi Murid Tadika.(Doctoral dissertation, Universiti Sains Malaysia.

Oberfoell, A. \& Correia, A. (2016). Understanding the role of the modality principle in multimedia learning enviroments. Journal of Computer Assisted Learning. 32(6), 607-617. doi:10.1111/jcal.12157

Rusell, J.D. (1974). Modular Instruction: A guide to the design, selection, utilization and evaluation of modular materials. United States: Publishing Company.

Sarkar, S. (2012). The Role of Information and Communication Technology (ICT) in Higher Education for the $21^{\text {st }}$ Century. The Science Probe, 1(1), 30-41.

Schrum, L., \& Levin, B. B. (2015). Leading $21^{\text {st }}$ Century Schools: Harnessing Technology for engagement and achievement. USA: SAGE Publications Ltd.

Sezer, B., Yilmaz, F.G.K \& Yilmaz, R. (2013). Intergrating Technology into Classroom: The Leanercentered instructional Design. International Journal on New Trends in Education and Their Implications, 4(12), 134-144.

Alsagoff, S. A. (1981). Pengenalan pengajaran individu dengan tumpuan khas kepada modul pengajaran dan pembelajaran. In Malay. Jurnal Pendidik dan Pendidikan, 3(1), 54-62.

Smaldino, S. E, Lowther, D. L. \& Russell, J. D. (2012). Instructional Technology and Media for Learning. $10^{\text {th }}$ Edition. Boston, MA: Pearson Education.

Mustapa, S. I. S. \& Miskon, A. S. (2010). Guru dan cabaran semasa. In Malay. Selangor: Penerbitan Multimedia Sdn Bhd.

Tee, Z. K., Alvy W. F, Mariam Abu, Dalilah Mohd Rubi, Suriani Mohamed, Yee, M. H., et al. (2016). Tahap penguasaan teori dan amali dalam kalangan pelajar Ekonomi Rumah Tangga: Kajian persepsi di Universiti awam Malaysia. In Malay. Georgrafia Online, Malaysia Journal of society and space 12(3): 79-87.

The Ministry Of Education Malaysia (2013). Pelan Pembangunan Pendidikan Malaysia 2013-2025: Pendidikan pra sekolah hingga lepas menengah. In Malay. Putrajaya: Kementerian Pendidikan Malaysia. 
INTERNATIONAL JOURNAL OF ACADEMIC RESEARCH IN BUSINESS AND SOCIAL SCIENCES

Vol. 8, No. 11, Nov, 2018, E-ISSN: 2222-6990 (C) 2018 HRMARS

The Ministry Of Education Malaysia (2014). Kurikulum Abad ke-21. In Malay. Putrajaya: Bahagian Pembangunan Kurikulum

Wingo, M. T., Thomas, K. G., Thompson, W.G. \& Cook, D. A. (2015). Enhancing motivation with the "virtual" supervisory role: a randomized trial. BMC Medical Education, 15:76 doi10.1186/s12909-015-0348-8.

Witkin, B.R. \& Altschuld, J.W. (1995). Planning and Conducting Needs Assessment. A Practical Guide. USA:SAGE Publications Int. Retreived from https://books.google.com.my/books?isbn=0803958102

Yanika, K., Moon, F.C., Sharon, S. L. T., Alan, S. K. S. \& Sally, W. C. C. (2017). Development of an elearning Research Module Using Multimedia Instruction Approach. CIN: Computers, Informatics, Nursing, 35 (3): 158-166.

Yap, W. L. (2016). Transforming Conventional Teaching Classroom to Learner-Centred Teaching using Multimedia-mediated learning Module. International Journal of Information and education Technology, 6(2): 105-112 doi: 10.7763/IJIET.2016.v6.667

Yuksel, H. \& Yuksel, A. (2015). The effect of the computer assited instruction on the academic achievement and retention of technical programme students' in vocational foreign language. Procedia Social and Behavioral Sciences 174(2015): 2513-2518. doi:10.1016/j.sbspro.2015.01.924

Yusof, Y., Roddin, R., Awang, H. (2015). What students need, and what teacher did: The impact of teacher's teaching approaches to the development of students generic competences. Procedia Social and Behavioral Sciences 204: 36-44.

Jusoh, Z. (2014). Pendekatan Naratif dan Komunikatif terhadap motivasi dan keterlibatan dalam pembelajaran dan pencapaian kemahiran mengarang. (Doctoral dissertation). In Malay. Universiti Putra Malaysia, Serdang.

Yasak, Z. \& Alias, M. (2015). ICT integrations in TVET: Is it up to expectations? Procedia-Social Behavioral Sciences, 204(2015): 88-87. 